\title{
Pecans and Hurricanes
}

\author{
Bruce W. Wood ${ }^{1}$ \\ U.S. Department of Agriculture, Agricultural Research Service, Southeastern Fruit and Tree Nut Research \\ Laboratory, Byron, GA 31008-0087 \\ William Goff \\ Department of Horticulture, Auburn University, Auburn, AL 36849 \\ Monte Nesbitt \\ Gulf Coast Substation, Alabama Experiment Station, Fairhope, AL 3653
}

The ecosystems of much of the Gulf Coast Coastal Plain and adjacent regions of the United States have been exposed to two important natural events nearly every year. One is the occurrence of hurricanes-the Spanish version of "huracan," a word apparently adopted from the Taino Indians of Haiti to describe the "evil spirit of the wind" (i.e., typhoon in the western Pacific Ocean and cyclone in the Indian Ocean) (Dunn, 1964). These storms are vertically deep $(\approx 16$ $\mathrm{km})$ atmospheric vortexes with a broad diameter $(\approx 120-480 \mathrm{~km})$, violent, cyclonic whirl of air moving at speeds $\geq 120 \mathrm{~km} \cdot \mathrm{h}^{-1}$ (Trewartha, 1968). The other event is the ripening of pecan nuts_pi-'kan, a Natchez Indian term for the nut of Carya illinoinensis (Wangenh.) K. Koch (McHatton, 1957). The autumn nut ripening was so important to pre-Columbian aboriginal inhabitants that great numbers of Native Americans in Texas, and probably other areas as well, migrated, to camp for long periods along pecan-studded riverbanks and flood plains to harvest nuts for food and trade (Celiz, 1935). Thus, both pecan and hurricanes had a significant effect on the aboriginal inhabitants of the Gulf Coast Coastal Plain and adjacent regions, and continue to do so today.

The ability of hurricanes to damage ecosystems is obvious, and there is a multitude of published studies on various aspects; however, the nature of recovery is poorly studied for most components and subsystems. Similarly, little or no attention has been devoted to the effect of hurricanes on the domesticated pecan subsystem, the nature of recovery by affected trees and orchards or the future threat of hurricanes to the pecan industry. Unfortunately, almost all existing knowledge regarding recovery of trees and orchards is anecdotal. This article reviews what little information is available regarding recovery of pecan following hurricanes striking the Gulf and Atlantic Coasts of North America, and briefly addresses their past and future impact on the pecan industry.

\section{HISTORIC IMPACT}

\section{Notable losses}

The southeastern sector of the U.S. pecan industry has been plagued by hurricanes since its birth in the late $19^{\text {th }}$ and early $20^{\text {th }}$ centuries. Most notable among these is the near elimination of pecan production in Mississippi by a single storm, hurricane Camille-a meteorological Armageddon, the second most intense hurricane to hit the United States in recorded history (Longshore, 1998). It was a tightly coiled storm of extraordinary intensity and of rare meteorological violence, being only the second of two Category-5 storms known to have struck the continental United States.

The Mississippi industry is concentrated within $\approx 300 \mathrm{~km}$ from the coast of the Gulf of Mexico. Camille hit the Mississippi coast on 17 Aug. 1969 with winds of $\approx 304-336 \mathrm{~km} \cdot \mathrm{h}^{-1}$ (barometric pressure of $67.6 \mathrm{~cm}$ ) and dumped $\approx 76 \mathrm{~cm}$ of rainfall (Kilby and Converse, 1970; Longshore, 1998). Winds rapidly diminished to about $160 \mathrm{~km} \cdot \mathrm{h}^{-1}$ as Camille moved inland across the length of the state. Wind gusts up to $\approx 107 \mathrm{~km} \cdot \mathrm{h}^{-1}$ were common throughout much of the state as the storm

Received for publication 26 May 2000. Accepted for publication 7 June 2000. The cost of publishing this paper was defrayed in part by the payment of page charges. Under postal regulations, this paper therefore must be hereby marked advertisement solely to indicate this fact.

${ }^{1}$ Corresponding author. E-mail address: bwood@byronresearch.net gradually weakened while moving up the Cumberland Plateau and across the Appalachian Mountains before reentering the North Atlantic on 21 Aug. This single storm greatly damaged the state's pecan industry and totally eliminated its tung industry (Kilby and Converse, 1970). Pecan nut production in Mississippi in 1970, the year after the storm, was only $\approx 27 \%$ of the average of that for the previous 5 years.

A similar situation also occurred in Alabama, also a Gulf Coast region with a long and violent history of hurricanes. In fact, 41 hurricanes hit the Alabama coast from 1559-1996 (Longshore, 1998). In recent years, these include Camille (1969), Eloise (1975), Frederic (1979), Elena, Danny, and Juan (1985), and Erin and Opal (1995). Frederic in 1979 had a profound destructive effect on Alabama's pecan production, destroying $\approx 60 \%$ of the bearing trees in two counties that were responsible for $\approx 60 \%$ of the state's total production. Opal, on 4 Oct. 1995 , was especially destructive to the pecan industry, with $384^{+}$ $\mathrm{km} \cdot \mathrm{h}^{-1}$ winds near the coast and $\approx 80 \mathrm{~km} \cdot \mathrm{h}^{-1}$ wind gusts throughout most of the state (Wood, 1996). As many as $50 \%$ to $80 \%$ of the trees in many counties were destroyed. Opal was the strongest hurricane to reach land in the Gulf of Mexico area during October in recorded history (Kimberlain and Elsner, 1998).

South Georgia possesses the largest concentration of pecan production in the eastern United States, producing $\approx 30 \%$ to $40 \%$ of the U.S. crop in most years (U.S. Department of Agriculture, 1975-97; Wood et al., 1990). Although most of the pecan production zone within the state is $175-500 \mathrm{~km}$ from the Gulf Coast, and is relatively safe from the intense winds of hurricanes, most of the state's industry is vulnerable to substantial damage from storms tracking across the region. The state had 69 hurricanes and 30 tropical storms from 1752 to 1995 (Longshore, 1998). Eleven of the hurricanes had intensities of Category $-3^{+}$. The most devastating to the Georgia pecan industry was the Great Mobile Hurricane, hitting the state's orchards with $161 \mathrm{~km} \cdot \mathrm{h}^{-1}$ winds in 1952 (Longshore, 1998). Degenerate hurricanes, such as tropical storm Alberto, which hit southwestern Georgia 3 July 1994, also can cause great damage to pecan orchards. Although wind speeds had diminished enough to merit classification as only a tropical storm by the time Alberto entered Georgia, $\approx 112 \mathrm{~km} \cdot \mathrm{h}^{-1}$ wind gusts and $\approx 54$ $\mathrm{cm}$ of rain within $24 \mathrm{~h}$ caused considerable tree, nut, and limb loss over a wide area of the state, as well as a once-per-500-year flood in southwestern Georgia when it stalled after colliding with an entrenched high pressure system over the southern United States (Longshore, 1998).

\section{Tracks across production zones}

Thirty of the most economically damaging hurricanes in the United States since 1900 have tracked across key pecan production zones (Fig. 1A; Pielke and Landsea, 1998). The total area devoted to pecan production in the United States is $\approx 190,000$ ha (473,426 acres). Two primary zones are southern Georgia $(\approx 240 \times 240 \mathrm{~km})$ and a crescentshaped zone $(\approx 250 \times 750 \mathrm{~km})$ from near coastal to central Texas and then into central Oklahoma. Since 1900, both production zones have been subjected to at least six major hurricanes, plus several other lesser hurricanes and tropical storms. The natural northwestward and then northeastward curvature of hurricanes allows them to track along much of the length of these two zones.

The regions of the U.S. Atlantic coastline most likely ( $\geq 4 \%$ in a given year) to be hit by severe hurricanes (Cat. 3+) are the central Gulf 


\section{Tracks of major hurricanes \\ and pecan acreage}

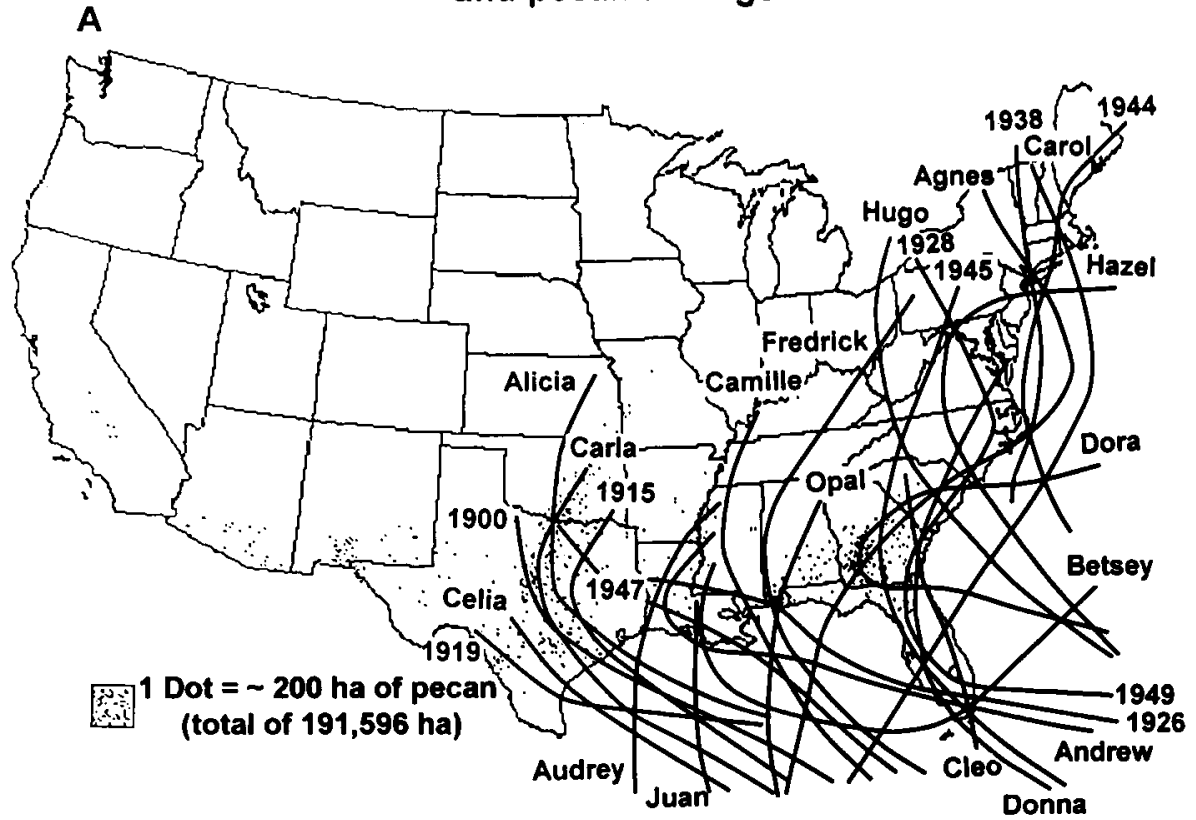

\section{Likelihood of hurricanes}

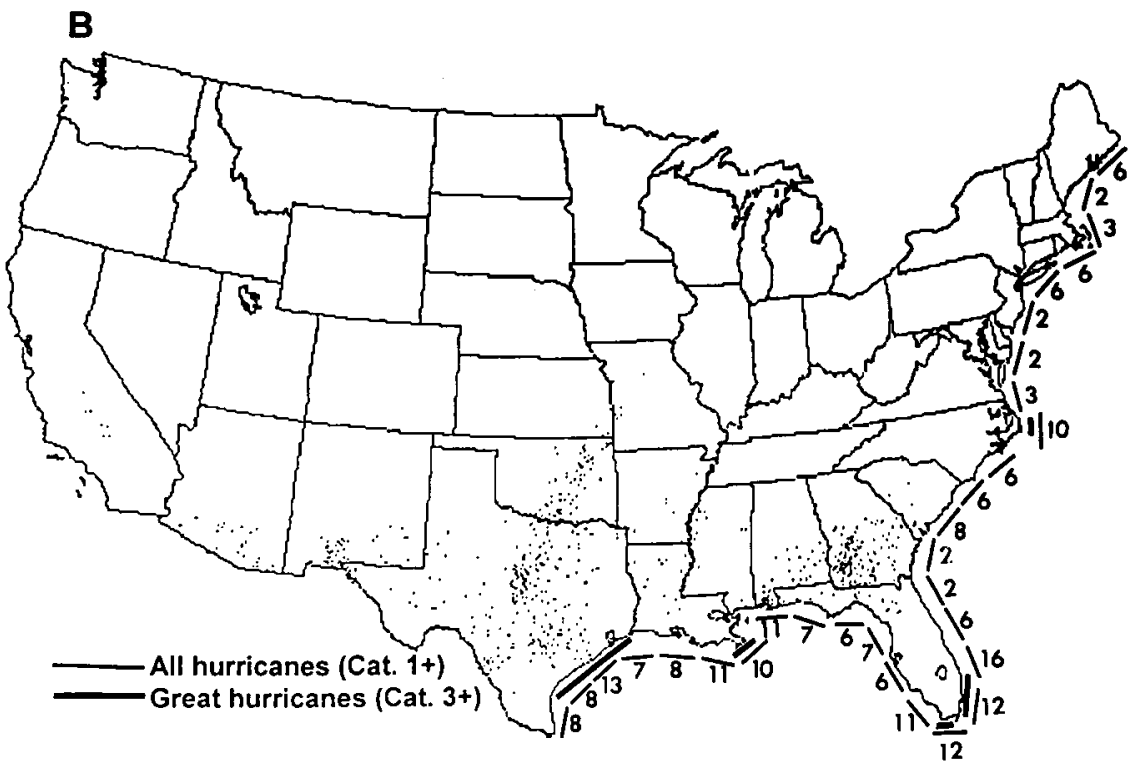

Fig. 1. (A) Tracks of major hurricanes (Cat. 3+) (Pielke and Landsea, 1998) relative to the location of pecan production zones) within the United States (U.S. Dept of Agriculture, 1999). (B) The probability that a hurricane (Cat. 1+) will hit in any one year a 160-km segment of the U.S. coastline and regions possessing a $\geq 4 \%$ probability of a great hurricane (Cat. 3+) hitting along the designated coastline in any one year (Brinkmannn, 1975; Longshore, 1998).

Coast of Texas, the tip of Louisiana, Florida and the tip of North Carolina (Fig. 1B; Longshore, 1998). In any one year there is an $\approx 13 \%$ chance that a hurricane (Cat. 1+) will strike the central coast of Texas. Such storms usually track in a northwestward curvature along the primary pecan production zone of Texas. The coast of Alabama-an area of substantial pecan production - has an $\approx 11 \%$ chance of being hit in any one year, plus there is the potential for recurvature across the Georgia production zone.

\section{POSITIVE ASPECTS OF HURRICANES}

Arthropods. Hurricanes have two very important positive effects. First is the substantial suppression of the arthropod population by heavy winds and rain. Populations of the especially detrimental sucking insects-such as the yellow pecan aphid [Melanocallis caryaefoliae Davis], the blackmargined aphid [Monellia caryella
Fitch], and the black pecan aphid [Melanocallis caryaefoliae Davis] are suppressed via physical effects from heavy rainfall (Kaakeh and Dutcher, 1992) and also probably by a proliferation of entomophagous fungi due to a relatively wet environment. The pecan leaf scorch mite [Eotetranychus hicoriae McGregor] is also a severe pest that is subject to population suppression for the same reasons as are aphids. These aphid and mite pests tend to be especially damaging in September and early October, when kernels are filling and healthy foliage is essential for next year's crop (Himrichs, 1962; Worley, 1979b). Orchards adjacent to the storm-track, but far enough away to avoid the damaging winds, often benefit substantially from arthropod suppression at a critical time of the year. Tree and crop damage by these pests is reduced, as well as associated pesticide costs. The impacts of hurricanes on the arthropod aspect of pecan orchard and tree ecosystems, and also the recovery of these systems, have not been studied, but merit investigation. 
Kernel filling. A second major positive effect of hurricanes is the deposition of needed rainfall at a very important time over a large sector of the pecan belt. This is important during the months of August-October, but especially important in September, because of the onset of kernel filling and the need to minimize tree stress (Sparks, 1996). An appropriately timed hurricane in the region can greatly benefit adjacent regional orchards that are outside the path of destruction. The Gulf Coast from Louisiana to northwestern Florida has a $6 \%$ to $14 \%$, long-term average chance of experiencing at least one hurricane per year (Brinkmann, 1975; Longshore, 1998). Northeastward tracking after landfall often results in the timely deposition of much needed and beneficial rainfall on the Georgia pecan belt, but without the damaging winds. Hence, land-falling Gulf Coast hurricanes in the upper Gulf of Mexico usually benefit the Georgia pecan industry, the region supplying about one-third of the U.S. production of pecans (U.S. Department of Agriculture, 1975-98).

The effect of hurricane-originated rainfall is especially beneficial to pecan-growing regions of Mexico. Most of these regions are in arid zones with substantial dependency upon irrigation water from mountain reservoirs. The most vulnerable zones to wind damage are the few scattered orchards in the states of Tamaulipas and Nuevo Leon. The bulk of the industry is in the states of Chihuahua and Coahuila, where associated heavy rainfall along the Sierra Madre Oriental mountains contributes much-needed water to mountainous reservoirs.

\section{DAMAGE AND RECOVERY}

\section{Forms of damage}

The nature of recovery of pecan trees to hurricane-induced damage is tightly linked to the type of damage received. Additionally, not all effects of hurricanes on trees and orchards are negative. The various negative and positive effects of hurricanes on trees and orchards are discussed below:

Uprooting. The most notable form of damage is the loss of trees due to uprooting by strong winds associated with the spiral rain-bands of hurricanes. These $\approx 3-30-\mathrm{km}$-wide circular bands are comprised of cumulus and cumulonimbus clouds that radiate outward $\approx 10-500 \mathrm{~km}$ from the eye wall (Longshore, 1998). Damage is most severe within less than $\approx 40 \mathrm{~km}$ of the shoreline because of the expansion and reduction in the speed of circulation when encountering the relatively rough surface of land (Brinkmann, 1975). Thus, pecan trees near open water are much more likely to be uprooted than are those inland. Such orchards are also exposed to tornado damage from one of the average of nine tornadoes spawned for each hurricane, these usually occurring 6-12 $\mathrm{h}$ prior to the arrival of hurricane-force winds (Brinkmann, 1975). When the hurricane landfalls, the most severe winds are encountered in the northeast quadrant of the storm, thus uprooting and limb damage will be greatest within this region.

Observations of tree damage and orchard recovery from several hurricanes hitting south Alabama indicate considerable variability in resistance to uprooting among cultivars (W.G. and M.N., unpublished data). Central leader trees generally display less damage than multileader trees; hence nut yields of such trees rapidly recover. 'Desirable', a popular, non-central-leader, southeastern cultivar, is especially susceptible to hurricane damage, whereas 'Elliott', a central leader tree, exhibits relatively little injury. Cultivars such as 'Jackson', 'Schley', and 'Choctaw', which have large and dense canopies with large leaflets, are prone to being uprooted. For example, 'Success', a large and spreading tree, is often more susceptible to uprooting by storms than are most other common cultivars in the Gulf Coast (e.g., 'Stuart' and 'Moore'). Tree counts following hurricane Elena in 1985 indicated that 'Cape Fear', also a relatively large and spreading tree, was 2.3 times as likely to be uprooted, or severely damaged, as was 'Stuart' (Sparks and Payne, 1986). Similarly, in tornado-damaged orchards of 'Stuart' and 'Schley', 78\% of the uprooted trees were 'Schley'. 'Schley' has a spreading and full canopy, whereas 'Stuart' has an upright and open canopy. Cultivars with open canopies therefore present less wind resistance and are less likely to be uprooted. Similar cultivar differences in susceptibility to wind damage have been reported for coconuts (Cocos mucifera L.) (Johnson, 1994).
Thus, orchard recovery is closely linked to cultivar, or tree canopy structure.

Observations indicate that tree size also plays a key role in recovery from hurricane damage. Young trees ( 1 to $\approx 5$ years old) have enough flexibility to withstand high winds, and $\approx 50-70$-year-old trees generally have enough bulk and anchorage to prevent their being uprooted by winds, but intermediate-aged trees are most susceptible to uprooting. Uprooting of the $\approx 50-70$-year-old trees is substantially enhanced if hurricane winds are accompanied with torrential rainfall. For example, hurricane Danny (July 1997), barely a Category-1 storm producing $\approx 112 \mathrm{~km} \cdot \mathrm{h}^{-1}$ wind, resulted in widespread uprooting of large trees after $50-89 \mathrm{~cm}$ of rainfall had fallen during the 48 -h preceding peak winds. Thus, saturated soils greatly contribute to uprooting.

Attempts to save uprooted trees have generally been unsuccessful. Observations (W.G. and M.N. and others with much hurricane experience) indicate that trees completely uprooted or blown to the ground should probably not be righted, because of poor survival. If trees are $10-12$ years old or younger, or have trunks less than $\approx 30 \mathrm{~cm}$ in diameter, survival rate is usually much better. There is also greater likelihood of recovery from uprooting if the soil is extremely wet when the trees blow down and major roots are unbroken. If major roots are broken, these trees sometimes survive, but they are usually not thrifty and easily uprooted again. Experience with these storms indicates that small trees should be righted quickly, before roots exposed to the air are killed. Righting of trees should be done when the soil is wet so as to prevent further root injury. Such trees will usually remain productive, especially if the canopy is pruned back to balance the loss of roots.

Hurricanes often cause trees to lean at various angles. The roots of leaning trees may or may not be pulled out of the ground, but often have sustained some injury. Long-term survival of leaning trees is unpredictable. Trees blown over to $\approx 45^{\circ}$ angles by Fredric in 1979 have remained productive for at least 20 years without straightening. Still, other trees leaning at small angles died a few years later. Straightening of leaning trees after the tree is dormant tends to be effective only with small trees (i.e., trunks less than $\approx 30 \mathrm{~cm}$ ). Again, wet soil conditions facilitate survival. Straightened trees usually require support from frames or wires. Subsequent nut yields from such trees are usually good if tree vigor is not noticeably diminished.

Limb breakage. The limb structure of most pecan cultivars tends to be more vulnerable to wind damage than that of wild trees, especially those growing in forest habits. This is because most cultivated trees do not possess a strong central leader, but rather an array of scaffold limbs displaying rather narrow crotch angles. A general rule with large trees, such as pecan, is that limb strength tends to increase with crotch angle (Brown, 1974). Long scaffolds with narrow crotch angles usually support a heavy crop load during hurricane season. Thus, the leveraging effects of crop load can easily enhance destruction of canopy structure. The immediate effect of limb breakage from a hurricane is loss of bearing potential and high pruning costs. There are often adverse long-term effects of limb breakage, because tree size and scope of damage often prohibit thorough corrective pruning or training. This results in rotting of heartwood that may reduce tree vigor and longevity. Waterspouts that form after branches are broken may be even less resistant to wind, and may break during severe thunderstorms in subsequent years.

Limb structure and tree form vary considerably among pecan cultivars (Wood, 1996), thus affecting susceptibility to damage. For example, the branch/leaf mosaic produced by nonpruned pecan trees tends to be either "open" (aperirecto) or "closed" (clistoforticat), with the clistoforticat form tending to catch more wind and therefore being more likely to break than the aperirecto form. Additionally, most cultivars exhibit rather narrow crotch angles (i.e., less than $\approx 57^{\circ}$ ), but $\approx 9 \%$ exhibit angles $>70^{\circ}$ and would therefore be expected to better withstand extreme winds. In 1979, hurricane Fredric, destroyed 60\% of the pecan trees in Baldwin and Mobile counties of south Alabama, with $>90 \%$ being uprooted in certain orchards. The predominant cultivars in these counties were 'Stuart', 'Desirable', and 'Success', with some 'Schley' and 'Moneymaker'. The damage to those cultivars with less suitable canopy characteristics (e.g., 'Desirable', 'Success', and 'Schley') was severe, and many trees were severely damaged. 'Stuart' generally had less limb breakage. 
Defoliation. If the winds associated with hurricanes do not uproot the tree or destroy limb structure, they often essentially defoliate the tree. Trees can refoliate, but if this happens before late October, the tree will not possess sufficient carbon reserves to set a fruit crop the following year (Himrichs, 1962; Worley, 1979a, 1979b), and will probably set a heavy crop of poorly filled fruit the second growing season. Because of the alternate bearing characteristics of pecan, the kernel quality of this crop is often poor. The crop developed the third year after the storm is once again small but of high kernel quality. Defoliation acts to trigger, and enhance, alternate bearing. Since most trees within an orchard are similarly damaged, the entire orchard begins to alternate

Loss of fruit. Hurricanes often cause major problems well beyond the path of devastation by causing the breakage and dropping to the orchard floor of thousands of small branches. This loss probably causes little harm to the tree or crop, but is of substantial expense to orchard recovery operations, and may delay harvest with consequent loss of price advantage associated with the earliest marketed nuts. Delayed harvest may cause a deterioration in kernel quality for those nuts lying exposed on the orchard floor. If hurricane-associated flooding occurs just after fruit ripening (as with hurricane Juan in 1985), nuts can be lost to flooding. This occurred along the Guadeloupe River in Texas in Oct. 1998, resulting in a near total loss of the bottomland crop along the lower half of the river's drainage basin.

Developing pecan fruit is highly susceptible to loss by hurricane damage. Such fruit can easily be knocked off the tree by collisions with limbs or branches. Additionally, subtle damage occurs to the internal structure of fruit, especially if storms occur during the late water stage (i.e., liquid endosperm) of kernel development, resulting in a massive fruit drop $\approx 7 \mathrm{~d}$ after the storm. We (W.G. and M.N.) observed that late kernel development and shuck dehiscence was abnormal following Hurricane Opal in 1995, an early October hurricane. Shucks did not dehisce completely or were delayed beyond the time of normal dehiscence. This "storm shock" may be a form of stress induced by sudden foliage loss and warm temperatures, coupled with twisting of peduncles or shuck (involucre) bruising.

Alternate bearing. Fruit production by individual trees and orchards of pecan is typically variable, exhibiting a strong tendency toward biennial bearing at the tree and orchard level, with epicycles of varying periods at regional levels (Wood, 1993). This is detrimental for the industry and growers because of unstable production, diminished nut quality during the "on" years, impaired marketing, and reduced income. While the details of the mechanisms regulating biennial bearing are unknown, levels of photoassimilate reserves play a critical role (Smith and Waugh, 1938; Wood, 1995; Worley, 1979a, $1979 b$ ), and the state of equilibrium between photosynthetic source and sink tissues acts to modulate the amplitude of the natural biennial cycle (Smith and Gallott, 1990; Smith et al., 1993; Wood, 1995). The loss of foliage and developing fruit due to hurricanes drastically alters the equilibrium between source and sink tissues such that yield instability is favored.

Biennial bearing induced by hurricanes is not only limited to recovering trees and orchards, but also appears to occur within regions, such as was the case in Mississippi after Camille in 1969 (Fig. 2). Annual in-shell nut production of improved cultivars in Mississippi the decade prior to Camille averaged $\approx 3400$ t per year, but only 1900 t per year the decade after Camille. The 1969 crop was estimated to be $\approx 4000 \mathrm{t}$, but dropped to $2800 \mathrm{t}$ because of direct storm damage. In-shell yield the following year was $900 \mathrm{t}$, probably $\approx 25 \%$ of what it would have been without Camille. In the nearly three decades since the hurricane, the Mississippi industry has never regained its pre-Camille production level. For example, production of in-shell nuts in 1998 was only 800 t. The intensities of bienniality (K; Pearce and DobersekUrbanc, 1967) in the 5-year periods prior to and after the storm were $\mathrm{K}=0.12$ and 0.31 , respectively; thus the intensity of alternate bearing increased by $258 \%$ during the 6 years after the storm. Production in 1970 , the year following the storm, was only $\approx 27 \%$ of the average for the previous 5 years. Thus, slow recovery from hurricane-enhanced alternate bearing can be a long-term problem.

Since most trees within an orchard are similarly damaged, the entire orchard begins to bear in pronounced biennial cycles, resulting

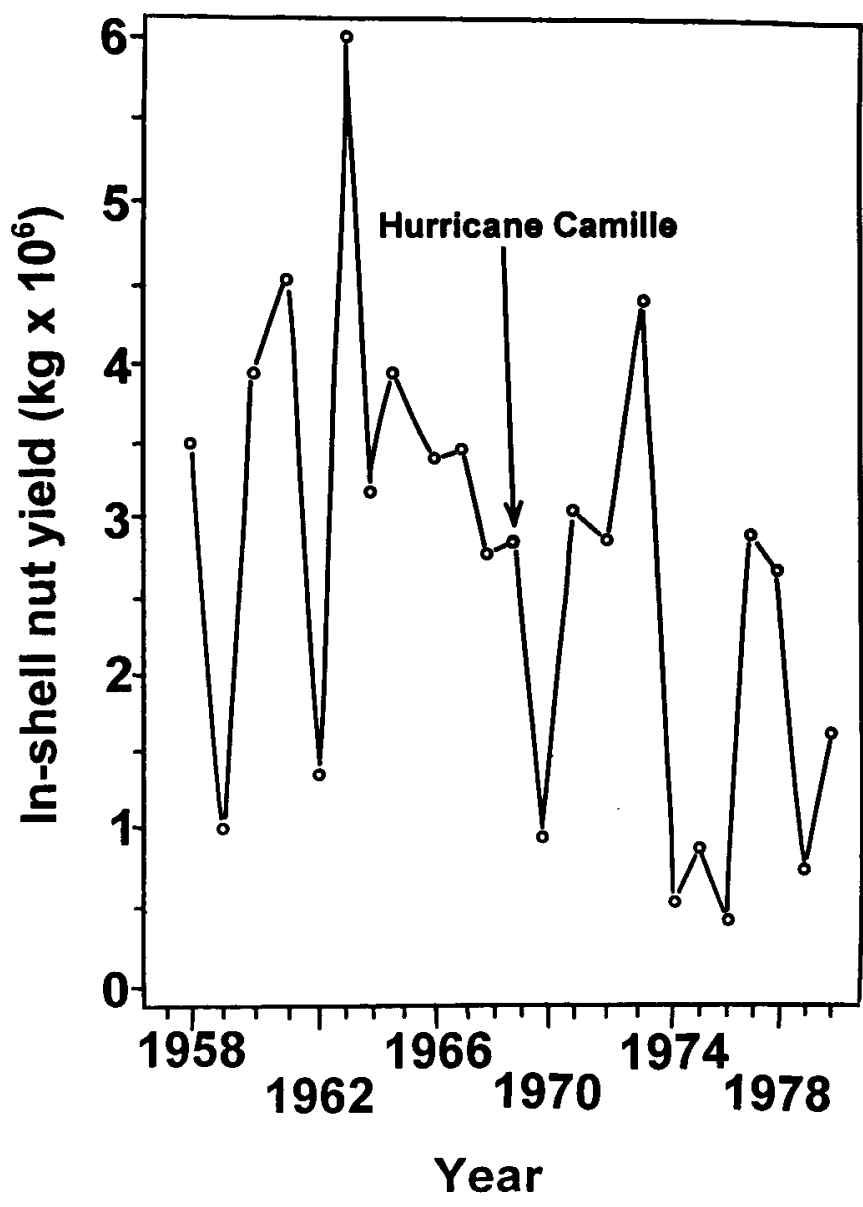

Fig. 2. Annual in-shell pecan production in Mississippi before and after hurricane Camille in 1969.

in little or no crop one year, followed by a heavy but low quality crop the next. This condition is catastrophic for commercial orchard operations (Wood, 1991). Such trees and orchards not only require 5-10 years to recover sufficiently to once again display relatively stable fruit production and nut quality, but also complicate cultural and pest management strategies.

Diseases. There is no evidence that tree longevity is adversely affected by hurricanes as a result of disease agents associated with "wind shock," as is apparent for peach [Prunus persica (L.) Batsch.]. Yield recovery by trees and orchards exposed to hurricanes is often slowed by failure to apply properly timed fungicide sprays that protect against pecan scab [Cladiosporium caryigenum (Ellis and Langl.) Gottwald] and other diseases. Fungicides possess little or no "kickback" activity against scab, thus delaying sprays because of wind, rain, or wet orchards can enhance scab problems (Wood and Reilly, 1999). These storms also can aggravate scab problems by spreading the conidia that are typically disseminated via rain (Latham, 1982). There is ample circumstantial evidence for the existence of several different races, or biotypes, of scab, some more virulent than others (Converse, 1960; Demaree, 1929). The dissemination of conidia over tens of thousands of hectares by winds potentially enhances the exposure of orchards within the storm-track to scab genotypes capable of causing substantial economic loss in future years.

\section{Factors that facilitate recovery}

The best approach to avoiding hurricane damage and associated long-term recovery problems is to avoid planting orchards in hurricane-prone regions. The pecan-growing region within the U.S. pecan belt exposed to highest risk is an $\approx 100-\mathrm{km}$ band from the TexasMexico border to the northwest coast of Florida and along the South Carolina and North Carolina coasts. Records indicate that orchards within these two zones have a $60 \%$ to $100 \%$ chance of being hit with 
a land-falling hurricane over a 10 -year period. Because pecan orchards exist for $\approx 100+$ years, orchards within this zone would be expected to be hit with several hurricanes over the life of the orchard. The northwestward curvature of the Atlantic coast of Georgia and the fact that most of the Georgia pecan belt is $>100 \mathrm{~km}$ from the coastline, means that the most important pecan-producing zone of the southeastern quadrant of the United States is fairly well-protected from direct hits by hurricanes, thus being exposed only to tropical storm class winds that cause relatively little damage.

Attention to the selection of cultivars should reduce susceptibility of trees to damage. Cultivars with strong (i.e., wide) crotch angles and central leaders are likely to resist winds better. Resistance to wind damage can be created by training to a central leader growth form and careful selection of scaffold limbs to produce strong crotches. Additionally, selection of cultivars with "open" rather than "closed" canopies should confer greater wind protection when trees are grown at standard spacings without pruning.

Another practice that is likely to minimize susceptibility to damage, although untested, is using hedge pruning techniques to keep tree height low and the orchard canopy relatively dense, thus minimizing tree exposure to winds and the associated leveraging effect on root systems (Wood, 1999). Hedge pruning and other pruning methods that reduced tree height and opened up canopies greatly reduced limb breakage and uprooting of trees of tropical fruit species exposed to hurricane Andrew in south Florida (Campbell et al., 1993). Under a hedging management system, even if orchard trees were blown over, their relatively small size would markedly reduce the time required to refill the vacated space with a transplant. In fact, the increasing popularity of transplanting large pecan trees would allow for refilling of the space within a few years, thus accelerating orchard recovery.

Pecan trees normally produce a large tap root if not grafted, or if the root system is not cut upon digging during transplanting. This tap root functions as an anchor that assists the tree in withstanding winds. If taproots are cut during transplanting they may not regrow, thus reducing tree anchorage and ability to withstand hurricane-force winds. Trees planted in sites where the water table is high develop a horizontally spreading, shallow root system. Thus, these trees are more susceptible to uprooting by winds. Orchards in hurricane- prone zones might benefit from unpruned tap roots. Seeds could be planted in the orchard, then grafted when the seedlings are of sufficient size.

\section{CONCLUSIONS}

While the intensity, frequency, and path of hurricanes into the pecan belts of the United States and Mexico remain unpredictable, enough is known about these patterns to provide information to guide the cultural and management decisions associated with pecan husbandry. Whether by serendipity or by design, a major portion of the U.S. pecan industry is located in Georgia, where this storm-susceptible crop is being cultivated in a moderately protected region of the southeastern U.S. pecan belt, while benefitting, at an important time of year, from rainfall during late summer and early autumn when soil moisture is low. A similar situation occurs in the major pecan production zone in eastern Texas.

Recovery of trees and orchards from hurricane-induced damage can be very slow, especially if trees are destroyed. The effects are diverse and poorly studied. Aside from the obvious loss of trees, limbs, and fruit, additional economic losses are associated with subtle reductions in nut yields due to disease, fruit shock, and loss of production. An increase in the magnitude of alternate bearing is perhaps the most long-lasting, adverse, biological side-effect. Its legacy is still felt, 30 years later, in post-Camille Mississippi and Alabama. Additionally, longevity of pecan trees and orchards ensures that recovery of orchard productivity and structure often spans several decades. This is coupled with a high probability of being substantially damaged by hurricanes during the lifetime of the tree or orchard. Therefore, these infrequent but large disturbances to trees and orchard systems merit greater consideration with regard to management in order to minimize damage and/or hasten recovery.

Dale et al. (1998) point out that orchard managers can (a) influence the orchard system prior to large, infrequent disturbances, such as hurricanes; (b) choose to do so after the hurricane; or (c) attempt to influence the recovery process. Prior to the hurricane, orchards and trees can be managed by either no action or via preventive measures. At present, few if any pecan orchards receive preventive management. Recovery efforts can either focus on managing the state of the orchard system immediately after the hurricane or managing the ongoing process of recovery. The high capital costs of pecan trees and orchards and their likelihood of exposure to hurricane- and tropical storm-force winds several times during their lifetimes, indicates that orchard management should include strategies to either reduce damage or to hasten recovery. An orchard far removed from hurricane zones is still likely to be exposed to strong winds from severe thunderstorms and tornados during its lifetime, therefore meriting similar management strategies. Some preemptive measures that are likely to reduce damage are to: a) recognize the risk of hurricane damage in a particular area and locate orchards so as to minimize exposure to strong winds; and b) establish orchards using wind-resistant cultivars planted on deep, well-drained soils, using trees with good taproots, and manage the canopy to strengthen limbs to reduce wind resistance (e.g., mechanical pruning and selective limb pruning).

Recovery can be hastened by ensuring that trees are maintained in good vigor, are not in a severe alternate bearing mode, and are kept small enough to minimize susceptibility to strong winds and to allow for rapid refilling of vacated space if trees are lost. The establishment of orchards in a relatively high density spatial pattern, such as a hedgerow, combined with the incorporation of an appropriate mechanical pruning strategy may be one of the most effective strategies for not only preventing damage by strong winds, but also for facilitating recovery from such damage. These strategies also have the advantage of diminishing the importance of relying on cultivars that are relatively resistant to wind damage, thus increasing management options.

\section{Literature Cited}

Brinkmann, W.A.R. 1975. Hurricane hazard in the United States: A research assessment. Inst. of Behavioral Sci., Univ. of Colorado Press, Boulder.

Brown, C.L. 1974. Growth and form, p. 125-165. In: M.H. Zimmermann and C.L. Brown (eds.). Trees: Structure and function. Springer-Verlag, New York.

Campbell, R.J. and C.W. Campbell, J. Crane, C. Balerdi, and S. Goldweber. 1993. Hurricane Andrew damages tropical fruit crops in south Florida. Fruit Var. J. 47:218-225.

Celiz, F.F. 1935. Diary of the Alarcon expedition into Texas, 1718-1719. Quivira Soc. Publ. 5:12-21. (Trans. I.C.F.L. Hoffman).

Converse, R.H. 1960. Physiological specialization of Fusicladium effusum and its evaluation in vitro. Phytopathology 50:527-531.

Dale, V.H., A.E. Lugo, J.A. MacMahon, and S.T.A. Pickett. 1998. Ecosystem management in the context of large, infrequent disturbances. Ecosystems $1: 546-557$.

Demaree, J.B. 1929. Behavior of Cladiosporium effusum on some varieties of pecan. J. Agr. Res. 38:363-370.

Dunn, G.E. 1964. Atlantic hurricanes. Louisiana State Univ. Press, Baton Rouge.

Himrichs, H.A. 1962. Pecan industry and some research developments in Oklahoma. Northern Nut Growers Assn. 58:80-85.

Johnston, C.F. 1994. Hurricane damage to different coconut varieties. Trop. Agr. 71:239-242.

Kaakeh, W. and J.D. Dutcher. 1992. Effect of rainfall on population abundance of aphids (Homoptera: Aphididae) on pecan. J. Entomol. Sci. 28:283-286.

Kilby, W.W. and R.B. Converse. 1970. Hurricane Camille damage to pecans in Mississippi. Proc. Southeastern Pecan Growers Assn. 63:120-128.

Kimberlain, T.B. and J.B. Elsner. 1998. The 1995 and 1996 North Atlantic hurricane seasons: A return of the tropical-only hurricane. J. Climate 11:2062-2068.

Latham, A.J. 1982. Effect of some weather factors and Fusicladium effusum conidium dispersal on pecan scab occurrence. Phytopathology 72:13391345 .

Longshore, D. 1998. Encyclopedia of hurricanes, typhoons, and cyclones. Facts on File, Inc., New York.

McHatton, T.H. 1957. The history, distribution and naming of the pecan. Proc. Southeastern Pecan Growers Assn. 50:10-34.

Pearce, S.C. and S. Dobersek-Urbanc. 1967. The measurement of irregularity in growth and cropping. J. Hort. Sci. 42:295-305. 
Pielke, R.A. and C.W. Landsea. 1998. Normalized hurricane damage in the United States: 1925-1995. Weather and Forecasting 13:621-631.

Smith, C.L. and J.G. Waugh. 1938. Seasonal variations in the carbohydrates and nitrogen content of roots of bearing pecan trees. J. Agr. Res. 57:449460.

Smith, M.W. and J.C. Gallott. 1990. Mechanical thinning of pecan fruit. HortScience 25:414-416.

Smith, M.W., W. Reid, B. Carroll, and B. Cheary. 1993. Mechanical fruit thinning influences fruit quality, yield, return fruit-set, and cold injury of pecan. HortScience 28:1081-1084.

Sparks, D. 1996. A climatic model for pecan production under humid conditions. J. Amer. Soc. Hort. Sci. 121:908-914.

Sparks, D. and J.A. Payne. 1986. Notes on severity of tornado damage to Stuart vs. Schley pecan trees. Annu. Rpt. Northern Nut Growers Assn. 77:79-80.

Trewartha, G.T. 1968. An introduction to climate. McGraw-Hill, New York.

U.S. Dept. of Agriculture. 1975-98. Agricultural statistics. U.S. Govt. Printing Office, Washington, D.C.

U.S. Dept. of Agriculture. 1999. 1992 Census of agriculture. Natl. Agr. Stat. Serv., Washington, D.C

Wood, B.W. 1991. Alternate bearing, p. 180-190. In: B.W. Wood and J.A.
Payne (eds.). Pecan husbandry: Challenges and opportunities. U.S. Dept. Agr., ARS-96.

Wood, B.W. 1993. Production characteristics of the United States pecan industry. J. Amer. Soc. Hort. Sci. 118:538-545.

Wood, B.W. 1995. Relationship of reproductive and vegetative characteristics of pecan to previous-season fruit development and post-ripening foliation period. J. Amer. Soc. Hort. Sci. 120:635-642.

Wood, B.W. 1996. Canopy morphology of pecan cultivars. HortScience 31:139-142.

Wood, B.W. 1999. Developing a new paradigm for pecan production, p. 102 105. In: D. McCraw, E. Herrera, and B.W. Wood (eds.). Pecan husbandry. U.S. Dept. of Agr. ARS-1998-04.

Wood, B.W., J.A. Payne, and L.J. Grauke. 1990. The rise of the United States pecan industry. HortScience 25:594, 721-723.

Wood, B.W. and C.C. Reilly. 1999. Pecan scab disease and its control. Pesticide Outlook 10:12-15.

Worley, R.E. 1979a. Fall defoliation date and seasonal carbohydrate concentration of pecan wood tissue. J. Amer. Soc. Hort. Sci. 104:195-199.

Worley, R.E. 1979b. Pecan yield, quality, nutlet set, and spring growth as a response to time of fall defoliation. J. Amer. Soc. Hort. Sci. 104:346-351. 